\title{
2: $223346310-223260765$
}

National Cancer Institute

\section{Source}

National Cancer Institute. 2:223346310-223260765. NCI Thesaurus. Code C42341.

Physical location of FRSB_Gene 